Investigaciones Fenomenológicas, n. 8, 2011, 61-76.

e-ISSN: $1885-1088$

\title{
THE PHENOMENOLOGICAL PROBLEM OF SENSE DATA IN PERCEPTION: ARON GURWITSCH AND EDMUND HUSSERL ON THE DOCTRINE OF HYLETIC DATA
}

\author{
Daniel Marcelle \\ Florida Atlantic University, Florida \\ marcelle@fau.edu
}

\begin{abstract}
In this article, I will discuss Aron Gurwitsch's criticism of Edmund Husserl's theory of hyletic data. First, Husserl's doctrine will be summarized in its earliest complete formulation. It will then be seen that Gurwitsch's problem with this doctrine is primarily due to his acceptance of gestalt theoretic organization. He conceives of hyletic data as being a kind of formless stuff that undergoes organization by morphetic components of the noesis, which represents a dualism in perception. Instead, Gurwitsch wants to show us that the organization of these contents is autochthonous. I will consider Gurwitsch's criticism against Husserl's own writings, and especially those that were not available to Gurwitsch. It will be seen that Husserl continues to develop this doctrine and that it very interestingly undergoes a kind of noematization and exhibits certain displays of autochthonous organization that in the end are not far from Gurwitsch's own conception of these affairs.
\end{abstract}

Keywords: Hyletic data, sense data, noesis, noema, Gestalt, perception, Edmund Husserl, Aron Gurwitsch.
Resumen: Este artículo versará sobre la crítica de Aron Gurwitsch de los data hyléticos de Edmund Husserl. En primer lugar, se resumirá la doctrina de Husserl en su primera formulación completa. A continuación, se verá que el problema de Gurwitsch con esta doctrina se debe principalmente a su aceptación de la organización teórica de la Gestalt. Él concibe los data hyléticos como una especie de material amorfo que se somete a organización por los componentes de morphé de la noesis, lo que representa un dualismo en la percepción. En cambio, Gurwitsch quiere mostrarnos que la organización de estos contenidos es autóctona. Se examinará la crítica de Gurwitsch acerca de los escritos del propio Husserl y especialmente de aquellos que no estuvieron al alcance de Gurwitsch. Se verá que Husserl sigue desarrollando esta doctrina y que curiosamente sufre una especie de noematización y muestra ciertas manifestaciones de organización autóctona que, a la postre, no están lejos de la concepción gurwitscheana de estos asuntos.

Palabras clave: Datos hiléticos, sens data, noesis, noema, Gestalt, percepción, Edmund Husserl, Aron Gurwitsch,

Noesis and noema are two moments of what Edmund Husserl the total act. They work in a parallel fashion, the noesis evanesces in time while constituting and the noema that is or can be identical throughout different acts as constituted. In a similar kind of structure, he distinguishes two really inherent mo- 
ments within the noesis itself being a kind of form and matter or, to use the language that he introduces, morphē and hylē respectively. Morphē are intentional or apprehensional and formative components, while hyle are a kind of non-intentional material, i. e., literally a "stuff"; hyletic data are more generally and commonly known as sense data, which are, in a way, organized or made intentional by morphetic activity. On their own, hyletic data are simply the sensuous aspect of mental processes, i. e., color data, tone data, tactile data, etc., and are not to be confused with appearing aspects of the transcendent object itself or even appearance thereof; hyletic data are really immanent or inherent to the act and are neither actual parts of the object itself nor noematic in any way. The idea is that these various fields of sense data, each pertaining to some sense, are synthesized together and made intentional to constitute objects as they appear. An example to help keep hyletic data and noematic appearances separated is that of the green color of the leaves of a tree as they appear, i. e., noematically, and the fantastic multiplicity of shades of green involved in the sensing or the apparent size changes with distance, which are the hyletic data.

Now, Aron Gurwitsch objects to this doctrine of hyletic data outright and altogether: "In the first place, the notion of hyletic data, the sense data of traditional philosophy and psychology, has to be abandoned"1 ${ }^{1}$. It is his position that this doctrine endorses a traditional dualistic theory of perception in which sense data that depend exclusively on external stimulation are by some supervenient organizing power made into perceptions. Hyletic data in such a case, then, are the elementary materials from which perception arises through some kind of apprehensional interpretation or formation of this material. As elemental they retain their identity strictly no matter how they are apprehended, i. e., the assumption would be that they maintain a kind of independence of the morphetic or apperceptive characters. The possibility of describing such data and such a process Gurwitsch believes to be beyond the powers of phenomenological method and that without such availability for description it becomes apparent

\footnotetext{
${ }^{1}$ Aron Gurwitsch, The Field of Consciousness: Theme, Thematic Field, and Margin, in The Collected Works of Aron Gurwitsch (1901-1973), vol. III, Dordrecht, Springer, 2010, pp. 41s.
} 
that there is no such noetic organizational activity. Instead it is descriptively revealed that organization is autochthonous to perception.

It is my position that Gurwitsch is correct in some ways on this matter, but in many ways Husserl's complex and detailed discussions of hyletic data do not fit so easily into the model of a traditional dualistic or two-strata theory of perception. It will be seen how such is exceeded in important ways in the case that Husserl makes. Ultimately, it is possible to even identify a kind of noematization of hyletic data in his work, possibly in a way that Gurwitsch himself would possibly accept. In the following, I will present a brief account of Husserl's position on hyletic data. Then I will explore some of Gurwitsch's problems to some detail to which I will offer a more complex view of Husserl's position that in some important ways seems to resist these certain aspects of this criticism. Finally, I will consider Gurwitsch's important contribution to this discussion in terms of a more holistic approach to perception and a new understanding of the role of noeses in a correlation conception of consciousness that may obsoletize any need for hyletic data.

\section{A General Summary of Husserl's Formulation of Hyletic Data}

Husserl introduces the distinction of hylē and morphē in order to correct for some of the problems that have arisen out of the tradition of sensation in psychology. In the same way that Husserl introduces the distinction of noesis and noema in order to amend Brentano's confusion of intentional acts and objects with his position of "mental inexistence", the introduction of hyletic data in Ideas $I$ is designed to work out certain aspects of this same problem. The traditional psychologistic account of sensation is that such are physically caused by external objects stimulating our sense organs. The philosophical problem with this position is that the causes of sensation are, then, mediate and indirectly available in some transcendent worldly domain not immediately or directly available to consciousness, i. e., these causes are, then, beyond the powers of phenomenological description. Sensations are in this way the point of access to the transcendent material world. For Husserl in his Logical Investigations sensations become the "stuff" of both elementary apprehension and those higher level acts founded upon these, which is the formulation that will factor largely 
in Gurwitsch's understanding of these affairs. Thus, in the case of perceiving a word, there is the simple apprehension of a physical shape and the higher sense founded upon this of a word's meaning. Sensation also plays the role of fulfillment for perceptual apprehensions. This still is naïve in the sense that sensation plays the role of a kind of "window" to transcendent reality, but this will be corrected in Ideas $I$ with the epochē of the transcendent domain.

In Ideas $I$ we are left with a transcendental residue of sensation that cannot serve as a window to the transcendent because transcendence has been suspended by the epochē. Instead, sensation is now a moment within the correlation itself as a kind of noetic parallel to the noema. The primary difference, though, is that hyletic data are not objectifying on their own, i. e., they do not of themselves present us with an identical object through several moments of time. Hyletic data are not moments of the object as experienced, but moments of the experiencing of that object and they pertain to all five fields of the senses. Husserl describes hylē and morphē in the following way:

\footnotetext{
We find such concrete really immanental Data as components in more inclusive concrete mental processes which are intentive as wholes; and, more particularly, we find those sensuous moments overlaid by a stratum which, as it were, "animates", which bestows sense [...] a stratum by which precisely the concrete intentive mental process arises from the sensuous, which has in itself nothing pertaining to intentionality. ${ }^{2}$
}

Further on in the same section, Husserl, in Kantian fashion, refers to hyletic data as "formless stuff" and morphē as "stuffless forms". More than being just the data of sensuous intuition, hyletic data for Husserl include the emotional and volitional as well. If we hear a violin, to use Husserl's example, or a baby crying or television in another room, the hyletic data refer to the sound without the assumption that the sound is produced by some real violin, baby, or television set; we are just concentrating on the qualitatively distinctive tone without objective reference, which may be easier in the unfamiliar or experiences of impressionism or modern art designed to elucidate such things. Hyletic data intuitively fill our experience with the actual sensations of a certain object within a certain field of sensation. In this way they contribute to the experience of an object as being present and motivate our belief in the reality of such objects, which sustains the natural attitude.

\footnotetext{
2 Edmund Husserl, Ideas Pertaining to a Pure Phenomenology and to a Phenomenological Philosophy, Book I, Dordrecht, Kluwer Academic Publishers, 1998, p. 172. Trans. Frederick Kersten.
} 
In order to understand hyletic data better it is good to contrast such with their noematic counterparts in the case of simple perception. The example that Husserl uses is that of looking at a tree with interest in the color of the trunk. This color is noematic and belongs to the tree as it is perceived. On the noetic side, Husserl says that we "find in it 'something like color': namely, the 'sensed color', that hyletic moment of the concrete mental process by which the noematic, or 'objective', color is adumbrated" ${ }^{\prime 3}$._The noematic color maintains an identity throughout changes, while the hyletic data are in a continuous flux of change and multiplicity of sensed colors from which the noematic unity is constituted. Husserl writes:

The color of the seen physical thing is, of essential necessity, not a really inherent moment of the consciousness of color; it appears, but while it is appearing the appearance can and must, in the case of a legitimating experience, be continually changing. The same color appears "in" continuous multiplicities of color adumbrations. ${ }^{4}$

We say the tree trunk is "brown", but in the actual sensing of it the multiplicity of shades of brown can reach to a qualitative infinity. The varying appearance of the tree as one either approaches it or backs away from it also exemplifies the different roles played conjunctively by hyletic data and noemata. It would appear that the tree increases in size as one approaches it and decreases as one backs away. Noematically speaking, the tree has not changed size whatsoever and remains constant throughout this multiplicity of varying appearances. It is through the hyletic data that we can account for these changing appearances, which is interesting. On a more mundane note, this phenomenon makes possible snap-shots of one's companions "holding" the Eiffel Tower in the palm of their hands.

Husserl does discuss hyletic data as being somehow "animated" by a kind of noetic activity, which goes against the charge of elementalism. The idea is that if we analyze our sensuous experiences we will find, on the one hand, a kind of immanent sensuous data, i. e., hyle, and on the other a formative activity, i. e., morphe, together constituting objective experience. In one place he describes such in the following way:

${ }^{3}$ Ibidem, p. 202.

${ }^{4}$ Ibidem, p. 74. 
We find such concrete really immanental Data as components in more inclusive concrete mental processes which are intentive as wholes; and, more particularly, we find those sensuous moments overlaid by a stratum which, as it were, "animates", which bestows sense (or essentially involves a bestowing of sense -a stratum by which precisely the concrete intentive mental process arises from the sensuous, which has in itself nothing pertaining to intention-nality. ${ }^{5}$

It is through this animation, then, that our sensations lend themselves to become perceptions of objects and the objective world. Gurwitsch accurately summarizes Husserl in the following way:

[B]y themselves hyletic data are not perspectival perceptual appearances of things; taken in themselves, they have no presentational function. That function is bestowed on them by the apperceptive characters which synthesize hyletic data of different compartments of sensibility and transform them into perceptual appearances of things. As a result of such synthesis, there arises the consciousness of one intersensorial object which, as identically the same, can be perceived under its visual, tactile, and other aspects, and also the consciousness of perceptual space which, as numerically identical, can be both seen and touched ${ }^{6}$.

Now that we have a decent understanding of Hyletic data in Husserlian terms, let us go on now to see how Gurwitsch comes to reject this theory of perception.

\section{GuRWITSCH'S UndeRSTANDING OF THE DOCTRINE OF HyLETIC DATA AND CASE FOR ITS REJECTION}

Gurwitsch understands Husserl's doctrine of hyletic data in the following way. In order to explain perceptual experience, Husserl introduces a two-strata (dualistic) theory composed of sensuous hyletic data and organizational noetic acts or morphē. Hyletic data are the elements or raw sense data, which are actively structured and bestowed with meaning by the higher level morphe without which they would not be organized or structured whatsoever, which is a strong claim of his; hyletic data are in this sense just a "stuff" that maintains its elemental identity throughout different sense-bestowings or apprehensions.

\footnotetext{
${ }^{5}$ Ibidem, p. 172.

${ }^{6}$ Aron Gurwitsch, "Edmund Husserl's Conception of Phenomenological Psychology", in Phenomenology and the Theory of Science, Evanston, IL, Northwestern University Press, 1974, p. 100. Edited by Lester Embree.
} 
Gurwitsch describes this two-strata structure in the following way: "percepts are asserted to grow out of mere sense-data owing to supervenient factors (of whatever kind and description) by means of which sensations are interpreted and meaning is bestowed upon them" ${ }^{\prime 7}$. It is possible to illustrate the manner in which hylē and morphē work together using Husserl's example of a written word. On the one hand there is the physical manifestation of the word, which in this case is the dark ink on a light background of paper, or in hyletic terms the sensing of contiguous light and dark color data. When on the other hand we attend to the signification of the word, we are bestowing this material with the structure of meaning, which is the contribution of morphē. It is by the influence of morphe that the black sense data becomes letters against a light background. Morphē in this way are founded upon the underlying hyletic data. Gurwitsch believes that Carl Stumpf's distinction of "appearance" and "function" most likely influenced Husserl to adopt this position of hylē and morphē.

In this doctrine of hyletic data, Gurwitsch identifies something like elemental or supervenient organization. He believes that it implies that hyletic data on their own are absolutely devoid of structure and organization. He writes: "Hyle itself means nothing but is merely given, a multitude of contents which acquires sense and order only through noetic functions. The hyletic itself is 'formless stuff', merely present and nothing more ${ }^{\prime 8}$. According to Gurwitsch, the implications of such a theory are untenable, which include the problem of descriptively confirming raw and formless hyletic data, problems pertaining to the assumption that hyletic data somehow remain unaffected by apprehensional changes, and the general problem of an elemental or supervenient theory of organization. The lattermost point, of course, is the crux of Gurwitsch's argument against Husserl's doctrine and informs the other points. The importance of this is that Gurwitsch believes that the rejection of this doctrine leads to a strict correlation theory of intentionality losing any understanding of noeses to be animating or organizing agents of any kind, which, among other things, has the benefit of elegance.

\footnotetext{
${ }^{7}$ Aron Gurwitsch, The Field of Consciousness: Theme, Thematic Field, and Margin, p. 86.

${ }^{8}$ Aron Gurwitsch, "Phenomenology of Thematics and of the Pure Ego: Studies of the Relation between Gestalt Theory and henomenology", in The Collected Works of Aron Gurwitsch (1901-1973), vol. II: Studies in Psychology and Phenomenology, Dordrecht, Springer, 2010, p. 281. Edited by Fred Kersten.
} 
It is difficult and, according to Gurwitsch, impossible to descriptively confirm raw hyletic data. If the relationship of morphe to hyle is as founded to founding, then morphē requires or even presupposes hyletic data as its physical substratum, which effectively blends the two into a total act. Gurwitsch has no problem with this, but points out that if this is the case then a third noetic stratum mediating between hylē and morphē would have to be assumed in order to explain the articulation and structure of what are assumed to be formless hyletic data. What this means is that formless hyletic data as formless are impossible to phenomenologically confirm in that they are unavailable for description. Ultimately, Gurwitsch makes the point that it is impossible to abstractively separate hylē and morphē in order to consider them on their own for the reason that such would change what is given into something absolutely foreign, which we will come to understand as a problem in the following.

According to Gurwitsch, Husserl holds the position that hyletic data are a kind of foundational elemental material that is not modified other than apparently through the activity of sense-bestowal or even different sense-bestowals as can happen with the change of perspective or attitude as we have seen above. Instead, it rigidly maintains its identity and determined properties as whatever kind of "stuff" it happened to be before sense-bestowal and continues to be when left alone or with other kinds of sense-bestowal; its identity is constant, but somehow can be "molded" in different ways without really being affected by this. Gurwitsch describes the independence of hyletic data from morphetic or apprehensional activity in the following way: "Whatever the apperceptive characters bestow or confer on hyletic data does not change or modify the latter in their proper nature, but merely supervenes upon them"9 ${ }^{\prime 2}$ Gurwitsch identifies this position as the crux of the problem concerning Husserl's hylē/morphē doctrine. Husserl claims that these elements of perception can themselves be perceived in cases of perceptual doubt or ambiguity. The example of a wax figurine illustrates this. On first glance it may be that one sees some famous human being, but then on closer inspection it is revealed that such is a wax sculpture quite realistically resembling that person. In this case the same elemental material is animated in two different ways; one and the same stock of hyletic data is the common support for two overlapping appre-

\footnotetext{
${ }^{9}$ Aron Gurwitsch, "Edmund Husserl's Conception of Phenomenological Psychology", p. 100.
} 
hensions. Rather than assuming a constant and independent underlying layer of sensation that can be animated in various ways while retaining its identity like some kind of building blocks that can be put together in this way and that and then reassembled again or reapprehended as the case may be, it is rather Gurwitsch's position that the very identity and being of such data changes by shifts of attention with thematic modifications and the different roles engendered by such changes in organization: "The two-strata theory is untenable. [...] It is not the case that a new element $[\ldots]$ is superadded to the complex" ${ }^{\prime 10}$. It is not the case that anything is given without organization and structure, much less what is believed to be the foundation of perception. Gurwitsch summarizes his position in the following way:

Quite in general, sensuous material is not articulated by means of higher functions. What is immediately given, the phenomenological primal material, is given only as articulated and structured. Data devoid of all articulation, hyletic data in the strict sense, do not exist at all. What is given depends on the structural connections within which it appears. There are no data remaining unaffected by changes in organization, articulation, etc. ${ }^{11}$

Gurwitsch even points to similar prohibitions in Husserl's own work.

At this point, it is helpful to keep in mind Gurwitsch's Gestalt-informed meriology or whole-part theory of organization. In terms of organization, for him an absolutely independent part that strongly maintains its identity across change that is actual or apprehensional is utterly impossible. Instead, we have come to understand that parts are both functionally significant for the wholes of which they are a part and also contribute to the whole in playing the assigned role. Parts are not meaningful of themselves as any kind of elemental theory would necessitate, but derive this meaning from their context and the whole of which they are a part and in which they play a role. The example of a musical melody illustrates this point well. If we were to take the tone data of a melody as some kind of elemental hylē, which are animated by the melodic morphē, we would have to say that such should be the same in every melody and that it is just the apprehension that is different. It is rather the case that notes are actually different when included in different melodies. Certainly Mozart's Requiem and Beethoven's $9^{\text {th }}$ share some of the same notes, but we have to remark how

\footnotetext{
${ }^{10}$ Aron Gurwitsch, "Phenomenology of Thematics and of the Pure Ego: Studies of the Relation between Gestalt Theory and Phenomenology", p. 283.

${ }^{11}$ Ibidem, pp. 283.
} 
different their being is in these two contexts and how different any such note would be when given abstracted and on its own without a melodic context. When viewing the whole containing a certain part, from that standpoint the part dissolves into its context and role. If we were to isolate this part, if such is even possible in a given case, all things would change because the part would now be its own whole and our new theme. In application to the doctrine of hyletic date, Gurwitsch writes:

A separation between hyle and morphe is not even abstractively possible, for disregarding morphe and concentrating upon hyle alone entails a change in what is given. [...] Hyletic reflection as reflection on the hyle alone is thus not reflection in the proper sense. It is a thematic modification - namely, singling out. ${ }^{12}$

For all of these reasons Gurwitsch recommends relinquishing the doctrine of hyletic data and endorses a theory of intentionality in which noeses in general do not have an animating function, i. e., they are not "morphetic" in any way.

\section{Aspects of Husserl's Position that ExCEed GurWitsch's Critique}

Husserl would have to respond to Gurwitsch's criticisms that hyletic data have been therein misrepresented to some degree. A point of primary significance is that Husserl's texts do not definitively support the claim that hyletic data are an utterly formless and unorganized material. In many places throughout texts that were available for Gurwitsch it is clear that Husserl describes them as having form and organization apart from morphetic activity. It should be noted that Analysen zur Passiven Synthesis, which contains some of Husserl's best descriptions of formed and organized hyletic data in the discussions of association, was not published until after Gurwitsch's Field of Consciousness was published, which is the primary text in which he lodges his complaint against hyletic data. There are the "Thing and Space Lectures" of 1907 in which Husserl is known to have discussed hyletic data as inherently and premorphetically organized. Still, the Logical Investigations and Ideas I contain plenty of such clues that would have to be considered in an accurate formula-

12 Ibidem, p. 284. 
tion of Husserl's doctrine, which seem to be absent from Gurwitsch's consideration.

As early as the Logical Investigations, Husserl worked to clearly distinguish sensations as sensed, i. e., hyletic data, from objective or noematic aspects of the object that is perceived. In the context of working to avoid the psychologism of confusing aspects of the act with aspects of the object as he believes John Locke did, Husserl writes: "Sensations, animated by interpretations, present objective determinations in corresponding percepts of things, but they are not themselves these objective determinations ${ }^{\prime 13}$. This description is interesting because it is discussing the hylē-morphē structure that we introduced above making it clear that the morphē animate the hylē, but it is especially important because an example that Husserl gives of such a sensation is that of "shape" in addition to "color" and "smoothness". The latter two can be more accepted as being some kind of unorganized sensational stuff that Gurwitsch has been discussing, but the idea of some kind of a shape is difficult to accept as being essentially disorganized. Husserl employs the shape example again in Ideas $I$ in the following way:

One and the same shape appears continuously but always "in a different manner", always in different adumbrations of shape. [...] Each phase of the perception necessarily contains a determined content of adumbrations of color, adumbrations of shape, etc. They are included among "the data of sensations". ${ }^{14}$

Further on in the same paragraph, Husserl discusses the morphetic animation of such data emphasizing that such adumbrations are really inherent parts of the mental process and gives the example of the shape of a triangle as such an adumbration. These examples of organization taken from the Logical Investigations and Ideas $I$ are interesting in many ways, but it must be said are far from definitively demonstrating premorphetic organization in hyletic data. How are we to know in these that morphetic construings or interpretations are not already present? We have to look further to support the position that hyletic data of themselves display aspects of structure and organization.

\footnotetext{
${ }^{13}$ Edmund Husserl, Logical Investigations, Amherst, NY, Humanity Books, 2000². Vid. Investigation II, § 10, p. 356. Trans. John Niemeyer Findlay.

${ }_{14}$ Edmund Husserl, Ideas Pertaining to a Pure Phenomenology and to a Phenomenological Philosophy, p. 74.
} 
There is good evidence that hyletic data are not inherently chaotic in Husserl's Analyses Concerning Passive and Active Synthesis. William McKenna points out that in Husserl's discussions of the passive synthesis of the living present in this work that hyletic data are described in terms of exhibiting basic organizational structures ${ }^{15}$. Among such organizational structures are some that would be very interesting to Gurwitsch for the reason that it is no stretch at all to see aspects of gestalt organization implicit and, one could even say, autochthonous in these structures such as simple grouping (pairing) and the figureground relationship. Husserl makes the claim that hyletic data are organized according to basic principles such as similarity or dissimilarity of content and admits of the possibility of varying degrees of such. Husserl writes:

\begin{abstract}
But these necessarily have a unity through consciousness, a unity of kinship, as similar to one another or uniform with one another: Several discrete color-data in the visual field are grouped together; they are especially united by virtue of their similarity; and they are united in different ways as well. This kinship has its degrees and according to them it unites them now more strongly, now more weakly. ${ }^{16}$
\end{abstract}

The examples that Husserl employs are interesting in this case because they are clearly formed. He speaks of red squares overlapping blue ones as well as red triangles and so on. The case of the overlapping squares brings out two very interesting principles of hyletic organization. Husserl describes these in the following way: "(i) the synthetic-coinciding in a commonality, that is, in a sameness, and yet (ii) the synthetic conflict of particular matters of this commonality that repress one another reciprocally in the process of overlapping" ${ }^{17}$. We can imagine in the case of a blue square overlapping a red one that the blue data will be organized together as a unity and be, thus, distinct from the data of the red square. It is here that we see figure-ground organization taking place. In the case of simply one blue square the blue data and shape of that figure form a unity that is sharply distinguished from the background of dissimilar data that is not part of the figure. In similar ways we can see much the same happening in pairs or groups of similar objects that there is something in

\footnotetext{
${ }^{15}$ Cfr. William McKenna, "The Problem of Sense Data in Husserl's Theory of Perception", in Essays in Memory of Aron Gurwitsch, Lanham, MD, Center for Advanced Research in Phenomenology / University Press of America, 1984, pp. 223-240. Edited by Lester Embree.

${ }^{16}$ Edmund Husserl, Analyses Concerning Passive and Active Synthesis: Lectures on Transcendental Logic, Dordrecht, Kluwer Academic Publishers, 2001, p. 129. Trans. Anthony Steinbock.

${ }_{17}$ Ibidem, p. 130.
} 
either their uniformity or similarity that holds them together and distinguishes them from the background.

To be clear that Husserl is discussing hyletic data in these examples, we have to raise questions concerning the place of such data and the manner of its organization. In the first place, Husserl clearly has in mind hyletic data, which he is careful to proclaim in the following way early in the section: "we are speaking about immanent data, for example about concrete color-data in the unity of a streaming present ${ }^{\prime 18}$. Concerning the relationship of such similar or uniform data forming a figure or figures, he is careful to point out that such organization is not the adventitious association of like for like objects in the world, but is rather the inherent similarity of immanent contents that he describes as a "materially relevant community"19. The language is certainly striking considering the important status of relevancy in Gurwitsch's understanding of organization. Relevance is the glue, so to speak, of gestalt organization.

Additionally, in Husserl's Experience and Judgment he clearly defines hyletic data as being organized. In $\S 16$ of this work he wants to consider what he there names "passive data" by which he means hyletic data on its own, which he realizes is only possible abstractively. In order to render such data intuitive and bring it to view so to speak, he abstractively withholds from the formative affects of egoic sense-bestowings, i. e., morphetic activity, upon such passive data; "an abstractive turning-of-regard is always possible, in which we make this apperceptive substratum itself into an object ${ }^{\prime 20}$. With all such activity suspended, Husserl makes the following observation: "this field is still not a pure chaos, a mere 'swarm' of 'data'; it is a field of determinate structure, one of prominences and articulated particularities" ${ }^{\prime 21}$. The reason for this is that according to Husserl this pre-objective sensuous data is even at this level already the product of constitutive synthesis at least of internal time consciousness. Further on, he writes: "A particular element in the field is raised to prominence in such a way that it contrasts with something"22. Here Husserl is analyzing the

${ }^{18}$ Ibidem, p. 129.

${ }^{19}$ Ibidem, p. 133.

${ }^{20}$ Edmund Husserl, Experience and Judgment, Evanston, IL, Northwestern University Press, 1973, p. 73. Edited by Ludwig Landgrebe; translated by James S. Churchill and Karl Ameriks.

${ }^{21}$ Ibidem, pp. $72 \mathrm{~s}$.

22 Ibidem, pp. 73s. 
hyletic data of single sensuous fields, and points out that there is clearly a figure-ground organization present even at this level.

\section{CONCLUDING REMARKS}

There are two interesting directions that this research makes available. In Husserl, we see a noematization of hyletic data and in Gurwitsch we see a kind of purification of the correlation of noesis and noema. First, considering all of the clear evidence of Husserl discussing hyletic data in terms of being inherently structured and organized, it is difficult to agree completely with Gurwitsch that such in any way can be considered a formless chaos. It is interesting that in all of the points that we have discussed above that Husserl does not in any of these places explain such structure and organization as the product of supervenient morphē. He has focused the discussion on hyletic data abstractively from all else. We now have to wonder if he does not really have in mind something objective or, we may say, noematic, when he is discussing an organized hyletic data. There seems to be a noematization of hyletic data.

Gurwitsch, though, believes that the relinquishment of the doctrine of hyletic data has the important effect of requiring a redefinition of the role of noeses in the theory of intentionality. On the whole, he identifies in Husserl's concept of noesis a strong similarity to role and being of morphē, i. e., some kind of animating or organizing function that has been discussed extensively above. We are then left with a definition of noesis as an experienced act of consciousness in general: "After the distinction between hyle and morphe has been abandoned, the term 'noesis' extends to the experienced act of consciousness in its entirety"23. This enables a strictly correlative theory of intentionality in which noeses are real psychological events and their correlative noemata are ideal, atemporal, and reiterable.

Thus, it is possible to generally conclude that Gurwitsch's call for dismissing Husserl's doctrine of hyletic data and the hyle-morphe relationship altogether, it has been seen, is derived from his acceptance of gestalt theory primarily. He

${ }^{23}$ Aron Gurwitsch, "Phenomenology of Thematics and of the Pure Ego: Studies of the Relation between Gestalt Theory and Phenomenology", p. 284. 
advances his argument along two related lines. First of all, it is his position that the supposition of an inherently formless and chaotic stuff is impossible. According to gestalt theory, all things have form and meaning to some extent. His second reason for calling for the dismissal of the morphe-hyle distinction is that he has shown are the problems of supervenient organization. It is not the case that there are formative moments, which are the morphe, and that these somehow organize the formless hyle. In his work, Gurwitsch makes the consistent point that organization is autochthonous and inherent to the contents, which in this case are sensations. It is not the case that there is some supervenient agency bringing order to the orderless or two distinct strata within the noesis working in this way. Regarding Gurwitsch's criticism, it has been seen that he is not entirely correct in conceiving of Husserl's hyletic data as a disorganized, formless, stuff. Throughout Husserl's writings, including many that were available for Gurwitsch, hyletic data are often discussed in terms of being formed and organized even prior to the introduction of morphetic activity. Regarding the point of a supervenient theory of organization, i. e., a two-strata theory, Gurwitsch is accurate, though. Perhaps Husserl was on a trajectory that would eventually have come to something that Gurwitsch would accept as hyletic data became more and more noematic throughout his writings.

\section{OTHER BibliographicAL REFERENCES}

ARvidson, Sven P., The Sphere of Attention: Context and Margin, Dordrecht, Springer, 2006.

BRentANo, Franz, Psychologie vom empirischen Standpunkt, Leipzig, Felix Meiner, 1924.

GuRWITSCH, Aron, "Some Aspects and Developments of Gestalt Psychology", in The Collected Works of Aron Gurwitsch (1901-1973), vol. II: Studies in Psycho-logy and Phenomenology, edited by Fred Kersten, Dordrecht, Springer, 2010, pp. 1-62.

- "Author's Introduction", in The Collected Works of Aron Gurwitsch (19011973), vol. II: Studies in Phenomenology and Psychology, edited by Fred Kersten, Dordrecht, Springer, 2010, pp. xv-xxvi. 
MARCELLE, Daniel, "Aron Gurwitsch's Incipient Phenomenological Reduction: Another Way into Phenomenological Transcendental Philosophy from Psychology", Studia Phaenomenologica, vol. X (2010) 102-116.

- Making the Case for Gestalt Organization: Edmund Husserl and Aron Gurwitsch on the Problem of Independent Parts", in Advancing Phenomenology: Essays in Honor of Lester Embree. Contributions to Phenomenology, Dordrecht, Springer, 2010, pp. 197-222. Eds. Thomas Nenon and Philip Blosser. 